\title{
傾斜地管路内の木質バイオマス水力輸送に及ぼすチップアスペクト比の影響*
}

\author{
大政 光史 ${ }^{* 1}$, 廣川 敬康 ${ }^{* 1}$, 澤井 徹 ${ }^{* 1}$, 梶本 武志 $^{* 2}$
}

\section{Effect of Chip Aspect Ratio on Hydraulic Transportation of Woody Biomass by Hilly Terrain Pipelines}

\author{
Mitsushi OHMASA*1, Noriyasu HIROKAWA, Toru SAWAI and Takeshi KAJIMOTO \\ ${ }^{* 1}$ Kinki Univ. Dept. of Biomechanical and Human Factors Engineering \\ 930 Nishimitani, Kinokawa-shi, Wakayama, 649-6493 Japan
}

The unused biomass such as residues left on forest floor and unused portions of farm crops is considered as the most promising domestic resources in Japan. The utilization of unused biomass contributes to the environmental protection of forests as well as the reduction in exhaustion of carbon dioxide. To promote the utilization of woody biomass generated in forests and hilly agricultural areas, the efficiency for the transportation across hilly district regions has to be improved. In the present study, the hydraulic transportation system of wood chips by means of liquid film flow in sloped pipeline is proposed. The transportation limit of wood chips with various aspect ratios is investigated by using the test section imitating the hilly terrain pipeline. The results obtained are as follows. The maximum flow rate of wood chips is caused by the occurrence of hydraulic jump in horizontal flow, and is greatly affected by the liquid film flow rate and aspect ratio of wood chips. The analytical model to predict the stagnation of wood chips is presented, and it is found that the model gives a fairly good agreement with the experimental results of maximum flow rate of wood chips.

Key Words : Transportation of Wood Chip, Solid-Liquid Two-Phase Flow, Hilly Terrain Pipelines, Aspect Ratio of Wood Chip

\section{1. 緒言}

低炭素社会の構築，持続可能なエネルギー供給の方策の一つとして，再生可能・炭素中立であるバイオマス資 源の利活用が注目されている，バイオマス資源はその発生・利用形態により 2 つ側面を有する．1つは大量の 資源作物の生産等に基づくグローバルな資源，他の一つは小規模分散型の地産地消を基盤と寸るローカル資源で ある．国内で発生する森林バイオマスや農業系の非食用部といった未利用バイオマスは，貴重な国産の有機資源 であり, 後者のローカル資源に分類される. 未利用バイオマスは, 地域における農業林業の活性化, 森林保全, 国内自給率（木材，食糧，エネルギー）の向上とも結びつくことから，その活用の促進が強く求められている. 2010 年 12 月に閣議決定された「バイオマス活用推進基本計画」(1) においても，農作物非食用部や林地残材に対 して 2020 年を目標とした利用率の数值目標が設定されている.

しかしながら, 国内では林道や搬出路の整備が十分であるとは言い難く, 傾斜地に存在する切り捨て間伐材, 丘陵地果樹圃場で発生する剪定枝といった小規模のローカル資源を傾斜地から効率的に収集・搬出することが要 求されている. 資源収集・搬出の高効率化は，未利用バイオマスを持続的に活用していくために不可欠な基盤整

\footnotetext{
* 原稿受付 2012 年 3 月 22 日

${ }^{* 1}$ 正員, 近畿大学 生物理工学部（广649-6493 和歌山県紀の川市西三谷 930)

*2 和歌山県工業技術センター

E-mail: ohmasa@waka.kindai.ac.jp
} 
備の一つであり，「バイオマス活用推進基本計画」(1) でも解決すべき技術研究開発事項の一つとして取り上げら れている.

著者らは，高性能林業機械を使用しない簡易な搬出方法として，林地において破砕された木質チップを管路内 の液膜流に同伴させて輸送するシステムを提案し，システム運転時に問題となる管路閉塞によるチップの輸送限 界について検討してきた ${ }^{(2)}$. 一般的に, 傾斜度が $30^{\circ}$ を越える急傾斜地では路網整備は容易ではなく, 林道設 置には極めて大きな費用を要することが指摘されている ${ }^{(3)}$. 平均傾斜角 $30^{\circ}$ の傾斜不整地を模擬した管路を用 いて実験を行った結果，水平管路内で生じる跳水（液膜流の水位不連続性）が木質チップの閉塞を誘発し，木質 チップ輸送流量の限界に関与することを明らかにした．このとき，実験で使用したチップ形状は一辺 $3 \mathrm{~mm}$ の立 方体とした．これは，もつとも単純なチップ形状に対する輸送限界の基礎的な知見を得ることを目的としたため である.

本研究では, より現実的な水力輸送を検討するために木質チップのアスペクト比を変化させ，チップ形状がチ ップ最大輸送流量に及ぼす影響を明らかにする，さらに，最大輸送流量を予測するための解析方法を提示すると ともに，水力輸送システム運転時のエネルギー評価について考察を行う.

\section{2. 実験装置および方法}

実験装置の概略を図 1 に示す．実験装置は木質チップ供給系，水供給系，テストセクションおよび計測部によ り構成されている．木質チップは管路内で形成された液膜流に同伴されて輸送される．テストセクション管路は 図 2 に示すように, 傾斜不整地を想定して上流傾斜部および下流傾斜部を $30^{\circ}$ 下向きに固定した状態で, 中流部 の傾斜角を $\theta=0^{\circ} \quad$ (水平) および $\theta= \pm 2^{\circ}$ に設定した. テストセクション管路には柔軟で扁平しにくい透明 VS ホースを用いた。管路は内径 $d=32,50,65 \mathrm{~mm}$ の 3 通り，管路長は上流傾斜管 $1100 \mathrm{~mm}$, 下流傾斜管 $600 \mathrm{~mm}$, 中 流管 $850 \mathrm{~mm}$ である. 木質チップ供給装置は内径 $50 \mathrm{~mm}$ の塩ビパイプ, 直流電気ドリルおよびその先端に取り付 けた攪拌翼で製作し，直流電気ドリルの回転数を制御することにより木質チップの供給量を設定した．水循環装 置は貯水タンクから DC ギヤポンプで水を循環させ， DC ギヤポンプの回転数およびニードルバルブで流量を調 整した．使用した木質チップはバルサ材であり，その形状は， $3 \times 3 \times 3 \mathrm{~mm}, 6 \times 3 \times 3 \mathrm{~mm}, 9 \times 3 \times 3 \mathrm{~mm}$ の 3 通り

(以下，アスペクト比 $a=1 ， 2 ， 3$ のチップと呼ぶ)，木質チップ密度 $\rho_{S}$ は浸水時間を調整し，約 $600 ， 800,1000$ $\mathrm{kg} / \mathrm{m}^{3}$ の 3 通りに対して実験を行った。 $\rho_{S}$ の調整範囲は, スギ（含水率 $40 \%$ ）の密度約 $600 \mathrm{~kg} / \mathrm{m}^{3}$, コナラ, ウ 入剪定枝（含水率 $40 \%$ ）の密度約 $900 \mathrm{~kg} / \mathrm{m}^{3}$ を想定して決定した.

\section{3. 実験結果}

\section{$3 \cdot 1$ 木質チップの流動形態と最大輸送流量}

前報の結果 ${ }^{(2)}$ によれば，木質チップの閉塞すなわち輸送限界は 2 ヶ所で起こり得ることが確認されている. 1 つは固液混合部での閉塞, 他の一つは管路内での閉塞である. 前者は, 液膜流量が少ない場合 $\left(1 \sim 2 \times 10^{-5} \mathrm{~m}^{3} / \mathrm{s}\right.$ 以下）および管径が小さい場合 $(d=32 \mathrm{~mm})$ に観測される閉塞であり, 水力輸送現象に起因するものではない. 本研究では, 後者の固液二相流の流動特性に起因した閉塞のみを対象とする. さらに中流管の傾斜角が上向き $\theta$ $=+2^{\circ}$ ではチップ輸送が不可能であること, 下向き $\theta=-2^{\circ}$ と水平を比べると水平に設置した場合がチップ輸送 流量の下限值を与えることが前報と同様に確認できたため, 中流管を水平にした害験結果のみを示寸.

図 3, 図 4 に, アスペクト比 $a=1$ および $a=3$ の木質チップを用いた場合の内径 $50 \mathrm{~mm}$ の管路における木質チッ プの流動形態を示す。縦軸は木質チップ流量 $Q_{S}$, 横軸は液膜流量 $Q_{L}$ である. 図 3, 図 4 における (a), (b)は木質 チップ密度 $\rho_{S}$ が約 600 および $1000 \mathrm{~kg} / \mathrm{m}^{3}$ の結果に対応している. 図中の記号は以下の流動形態を表す.

○: 与えられた液膜流量で木質チップの水力輸送が可能.

$\times$ : 中流管における跳水位置（水位の不連続位置）で木質チップが閉塞.

$\square$ : 中流管で木質チップが液膜流幅全体にわたって並び停滞するが，木質チップの一部が液膜流内部に潜り込 み幾層に重なった状態で流動する. 


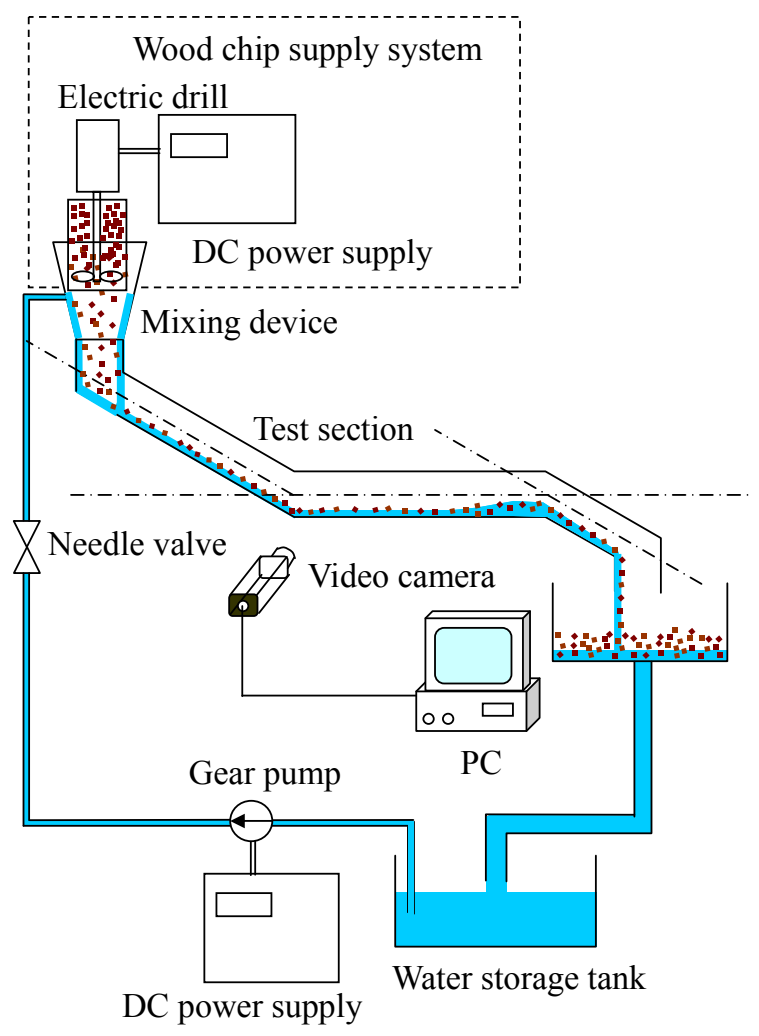

Fig.1 Experimental Apparatus

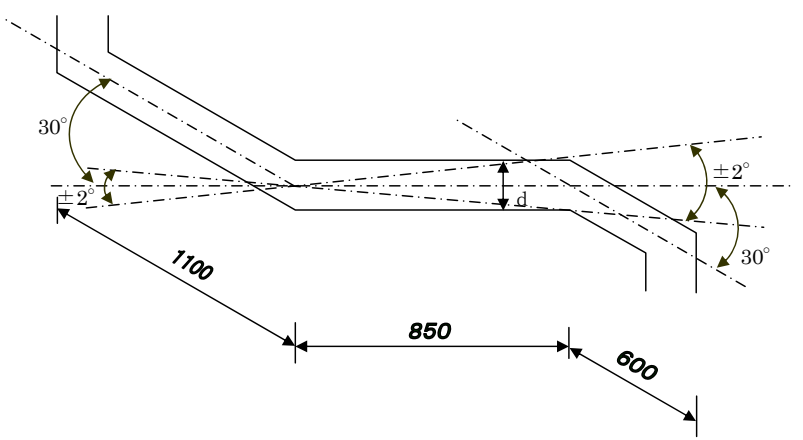

Fig.2 Test Section

なお，2つの記号が重なっている条件は，再現性を確認するための数回の実験で複数の結果が得られたことを 意味する. 図中の曲線は, 第 4 章の解析に基づく木質チップ最大輸送流量 $Q_{S \max }$ の予測結果であり, 詳細は後述 する.

いずれの図においても， $Q_{L}$ が大きくなるほど， $Q_{S \operatorname{smax}}$ は大きくなる. 図 3 と図 4 を比較した場合, 同一の $Q_{L}$, 同一の $\rho_{S}$ に対してアスペクト比 $a=1$ に比べ $a=3$ のチップでは, $Q_{\text {Smax }}$ が小さくなることがわかる. 管路内で木質 チップの閉塞が観測された位置は，水平な中流管において水位が低く速度の速い射流から水位が高く速度の遅い 常流に変化する跳水位置に対応している. 図 4 に示す $a=3$ のチップの場合, 射流領域では木質チップの大部分が 長辺方向（9mm の辺）を流れ方向と平行にして流動しているが，跳水直後の常流領域では，木質チップの回転が 観測され，チップの一部は長辺方向が流れ方向と垂直になった状態で流動する. アスペクト比が 1 より大きいチ ップの場合，常流部において長辺方向が流れ方向と垂直に配置されることが，最大輸送流量 $Q_{S \operatorname{smax}}$ の低下に結び ついている.この詳細については，第 4 章の解析モデルで最大輸送流量 $Q_{\operatorname{Smax}}$ に及ぼすチップアスペクト比の影 響を検討する. 


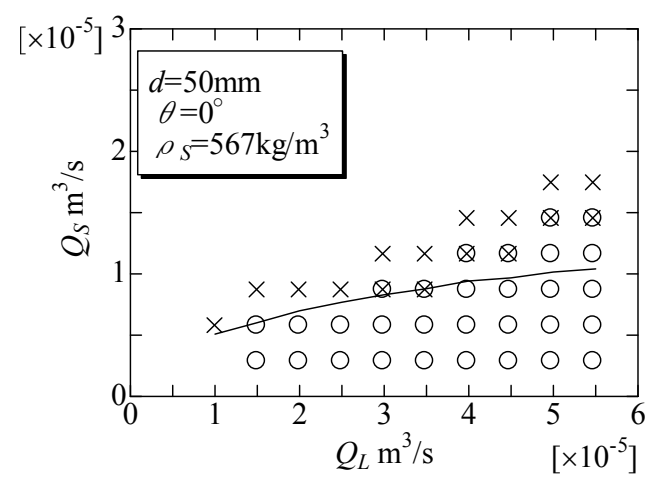

(a) $\rho_{S}=567 \mathrm{~kg} / \mathrm{m}^{3}$

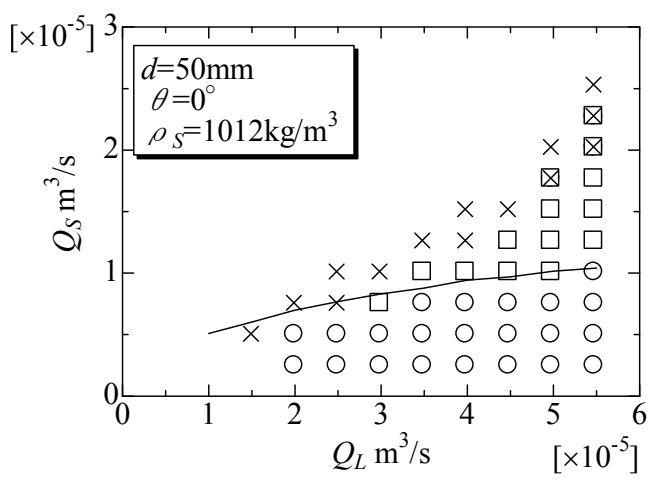

(b) $\rho_{S}=1012 \mathrm{~kg} / \mathrm{m}^{3}$

Fig. 3 Transportation limit of wood chip for $3 \times 3 \times 3 \mathrm{~mm} \quad(a=1)$

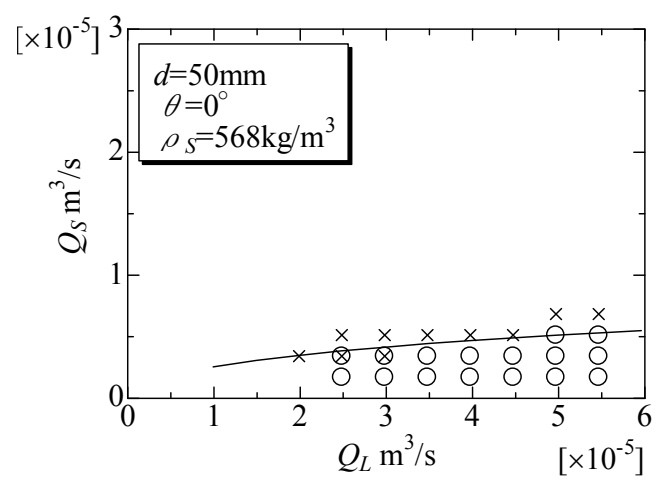

(a) $\rho_{S}=568 \mathrm{~kg} / \mathrm{m}^{3}$

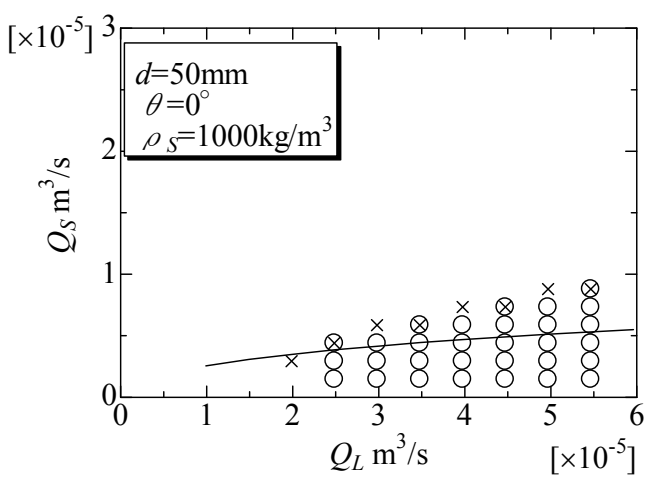

(b) $\rho_{S}=1000 \mathrm{~kg} / \mathrm{m}^{3}$

Fig.4 Transportation limit of wood chips for $9 \times 3 \times 3 \mathrm{~mm} \quad(a=3)$

また，図 3(b)に示す $\rho_{s}=1000 \mathrm{~kg} / \mathrm{m}^{3} ， a=1$ のチップにおける $\square$ 印の流動形態は，図 4(b)ではほとんど観測されな いことがわかる．これは， $a=3$ ではチップ長辺方向が流れ方向と垂直になることで，液膜流内部への潜り込み流

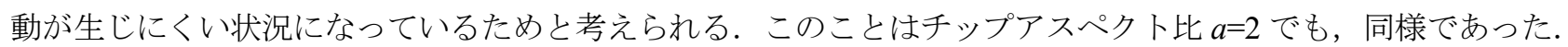

\section{$3 \cdot 2$ 木質チップ最大輸送流量に及ぼす液膜流量, チップ密度, 管径, チップアスペクト比の影響}

図 5 に $Q_{L}$ に対寸る木質チップ最大輸送流量 $Q_{S \operatorname{Smax}}$ の変化を, 木質チップ密度 $\rho_{S}$ をパラメータとして示寸. 図中 の曲線は実験データの近似曲線である. 図 5(a)のチップアスペクト比 $a=1$ では， $\rho_{S}$ が大きい場合に図 3(b)で示し た口印の流動形態が生じるため， $\rho_{S}$ 増大により $Q_{S \max }$ も大きくなる傾向がみられる. 一方，図 5(b)のチップアス ペクト比 $a=3$ では， $\rho_{S}$ の影響は小さい. $\square$ 印の流動形態を除けば, いずれのチップアスペクト比の場合も， $Q_{\operatorname{Smax}}$ に及ぼすチップ密度の影響は小さいと言える。

図 6 に $Q_{L}$ に対する木質チップ最大輸送流量 $Q_{S \operatorname{Smax}}$ の変化を, 管径 $d$ をパラメータとして示す. 図中の曲線は実 験データの近似曲線である. 図 6(a)のチップアスペクト比 $a=1$ では, $d$ が小さくなるにしたがい $Q_{\operatorname{Smax}}$ が減少する. $d=32 \mathrm{~mm}$ の場合, $d=65,50 \mathrm{~mm}$ に比べ $Q_{\text {Smax }}$ はかなり小さく, $Q_{L}$ が小さい条件では, 固液混合部で閉塞が発生す るためチップ輸送そのものが不可能な状況であった．図 6(b)のチップアスペクト比 $a=3$ では，定性的には図 6(a) と同様であるが， $d=32 \mathrm{~mm}$ では，いずれの $Q_{L}$ に対しても固液混合部で閉塞が生じたため，図中にデータが示され ていない.

図 7 に $Q_{L}$ に対する木質チップ最大輸送流量 $Q_{\text {Smax }}$ の変化を, チップアスペクト比 $a$ をパラメータとして示す. 図中の曲線は実験データの近似曲線である. 図 7(a), (b)に示すいずれの木質チップ密度においても, チップアス ペクト比の影響は大きく,$a$ が大きくなるほど $Q_{\text {Smax }}$ は小さくなる傾向がみられる. 


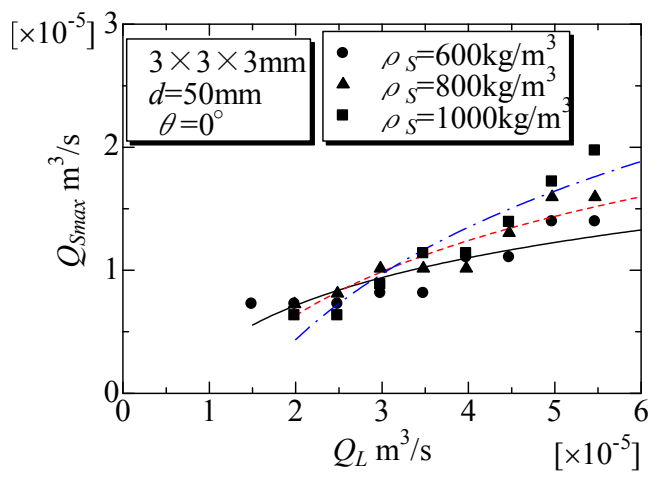

(a) $3 \times 3 \times 3 \mathrm{~mm} \quad(a=1)$

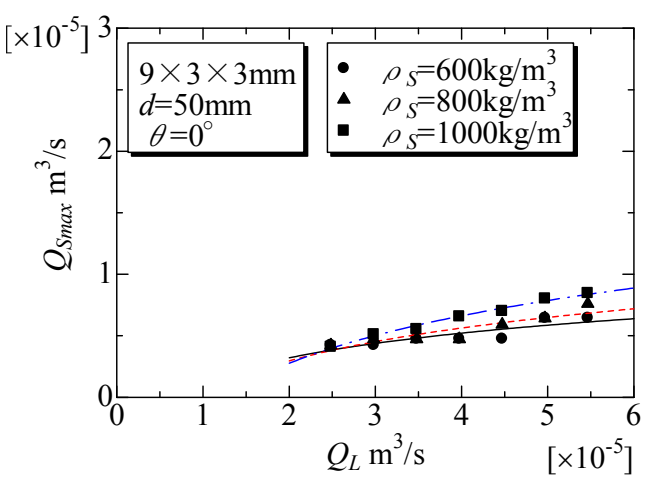

(b) $9 \times 3 \times 3 \mathrm{~mm} \quad(a=3)$

Fig.5 Effect of chip density on $Q_{\text {Smax }}$ for $d=50 \mathrm{~mm}$

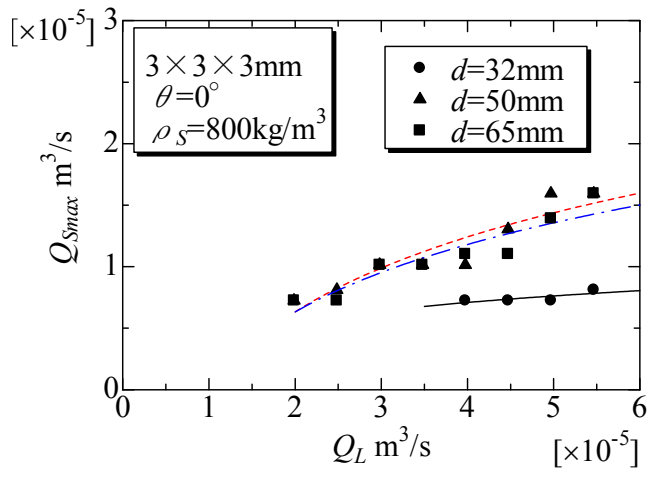

(a) $3 \times 3 \times 3 \mathrm{~mm} \quad(a=1)$

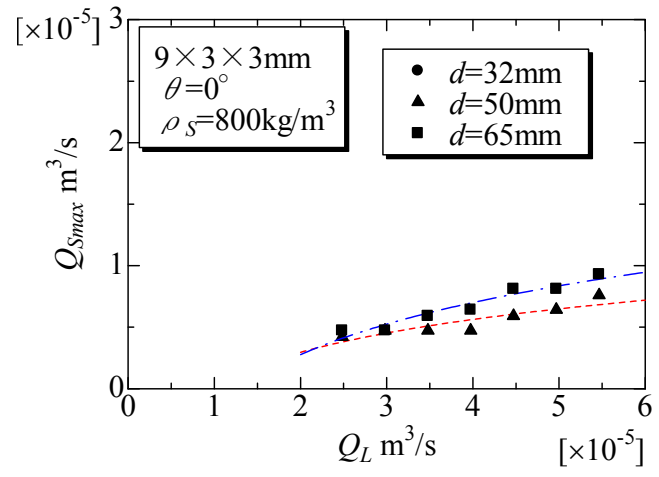

(b) $9 \times 3 \times 3 \mathrm{~mm} \quad(a=3)$

Fig.6 Effect of tube diameter on $Q_{\text {Smax }}$ for $\rho_{s}=800 \mathrm{~kg} / \mathrm{m}^{3}$

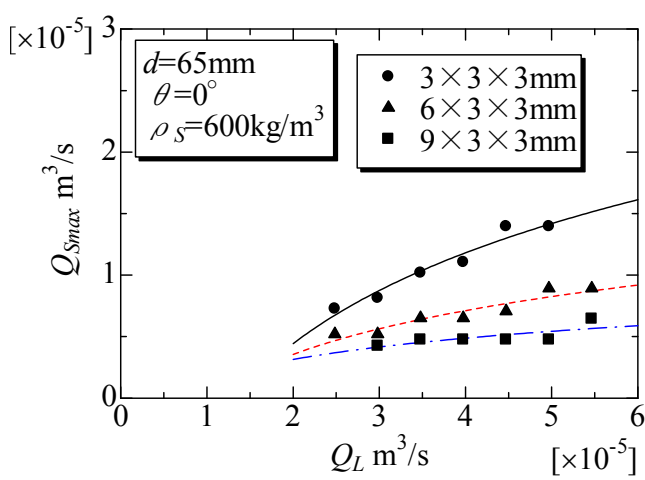

(a) $\rho_{\mathrm{s}}=600 \mathrm{~kg} / \mathrm{m}^{3}$

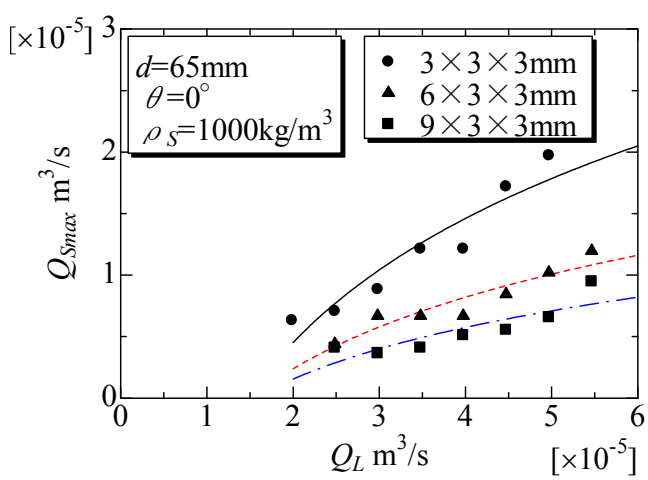

(b) $\rho_{\mathrm{s}}=1000 \mathrm{~kg} / \mathrm{m}^{3}$

Fig.7 Effect of chip aspect ratio on $Q_{\operatorname{Smax}}$ for $d=65 \mathrm{~mm}$

\section{$3 \cdot 3$ 木質チップ最大輸送流量に及ぼす異種アスペクト比チップ混合の影響}

前節において，木質チップ最大輸送流量 $Q_{\text {Smax }}$ がチップアスペクト比 $a$ によって大きく影響を受けることが明 らかになった．本節では，より現実的な木質チップの水力輸送を検討するために，異種アスペクト比の木質チッ プを混合し，木質チップ最大輸送流量 $Q_{\operatorname{Smax}}$ に及ぼす混合の影響を実験的に調べた.

図 8(a)にアスペクト比 $a=1$ およびアスペクト比 $a=3$ のチップを同体積比で混合して得られた木質チップの流動 形態の一例を示寸. 同体積比の混合であるため, チップ個数比としては, $a=1$ のチップ 3 に対して, $a=3$ のチッ プ 1 となる. 縦軸は木質チップ流量 $Q_{S}$, 横軸は液膜流量 $Q_{L}$ であり, 図中の記号は 3.1 節と同様である. 混合の 
影響を検討するために，図 8(b)および(c)にアスペクト比 $a=1$ と $a=3$ の流動形態を示す．図中の曲線は，第 4 章の 解析に基づく木質チップ最大輸送流量 $Q_{S \max }$ の予測結果である. 図 8 はいずれも， $d=50 \mathrm{~mm}, \rho_{S}=800 \mathrm{~kg} / \mathrm{m}^{3}$ で得ら れた結果であるが， $Q_{L}$ が大きくなるほど，木質チップ輸送限界流量 $Q_{S \operatorname{smax}}$ は大きくなる. 同一の $Q_{L}$ に対してみた 場合，異種アスペクト比混合の $Q_{\operatorname{Smax}}$ は単独アスペクト比 $a=1$ と $a=3$ の間の值をとることがわかる.

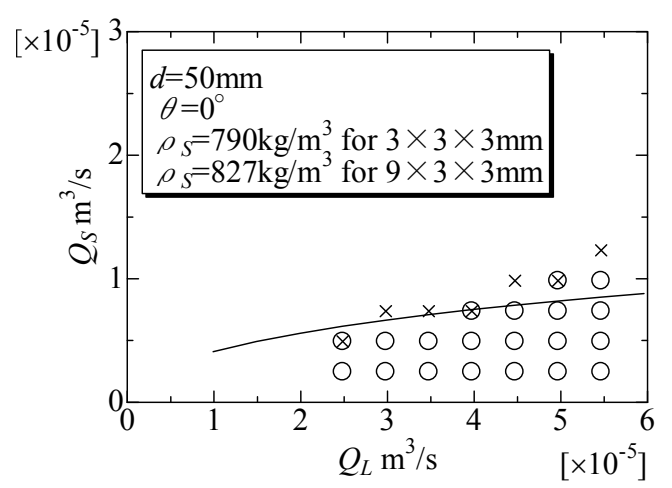

(a) Transportation limit of wood chips

for mixture of $3 \times 3 \times 3 \mathrm{~mm} \quad(a=1)$ and $9 \times 3 \times 3 \mathrm{~mm} \quad(a=3)$

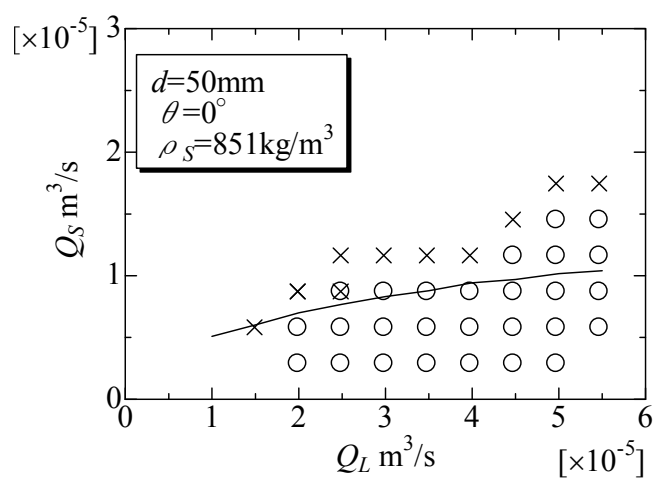

(b) Transportation limit of wood chip for $3 \times 3 \times 3 \mathrm{~mm} \quad(a=1)$

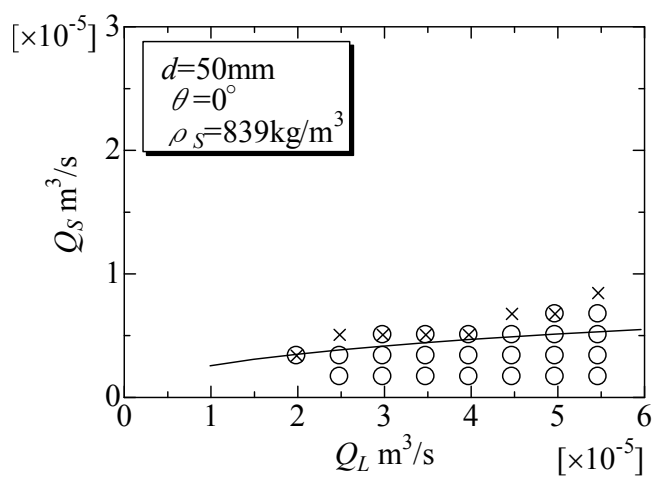

(c) Transportation limit of wood chip for $9 \times 3 \times 3 \mathrm{~mm} \quad(a=3)$

Fig.8 Effect of mixture of different aspect ratio wood chips on transportation limit 


\section{4. 木質チップ最大輸送流量の解析}

\section{$4 \cdot 1$ 管路内液膜流の解析}

図 9 に上流傾斜管から中流水平管の跳水付近までの液膜流とその断面を模式的に示す. 跳水の内部構造を無視 し，水平管における跳水現象の一次元解析を行う．跳水発生位置を含む検查面間においては，比力 $M_{0}$ に比へ底 面摩擦が無視し得るほど小さいものとすると，次式に示す比力の保存式が成立する.

$$
\left(M_{0}\right)_{2}-\left(M_{0}\right)_{1}=0
$$

ここで, $\left(M_{0}\right)_{1},\left(M_{0}\right)_{2}$ は跳水前後の射流部および常流部における比力であり, 次式で与えられる.

$$
\begin{aligned}
& \left(M_{0}\right)_{1}=\left(\frac{Q_{1}^{2}}{g A_{1}^{2}}+\frac{h_{m 1}}{2}\right) A_{1} \\
& \left(M_{0}\right)_{2}=\left(\frac{Q_{2}^{2}}{g A_{2}{ }^{2}}+\frac{h_{m 2}}{2}\right) A_{2}
\end{aligned}
$$

上式において，下付き添え字 1 と 2 は射流と常流を表す， $Q$ は液膜流の体積流量 $Q_{L}$ であり，液膜流の断面積 $A$ と液膜流速度 $v$ の積として与えられる. $g$ は重力加速度である. また, 断面積 $A$, 液膜流幅 $B$, 平均水深 $h_{m}$ は液 膜流幅の開き角 $\alpha$ と管路半径 $r$ を用いて次式のように表される.

$$
\begin{aligned}
& Q_{L}=A \cdot v \\
& A=\frac{r^{2}}{2}(\alpha-\sin \alpha) \\
& B=2 r \sin \frac{\alpha}{2} \\
& h_{m}=\frac{A}{B}=\frac{r}{4} \cdot \frac{\alpha-\sin \alpha}{\sin \frac{\alpha}{2}} \quad(0 \leq \alpha \leq \pi)
\end{aligned}
$$

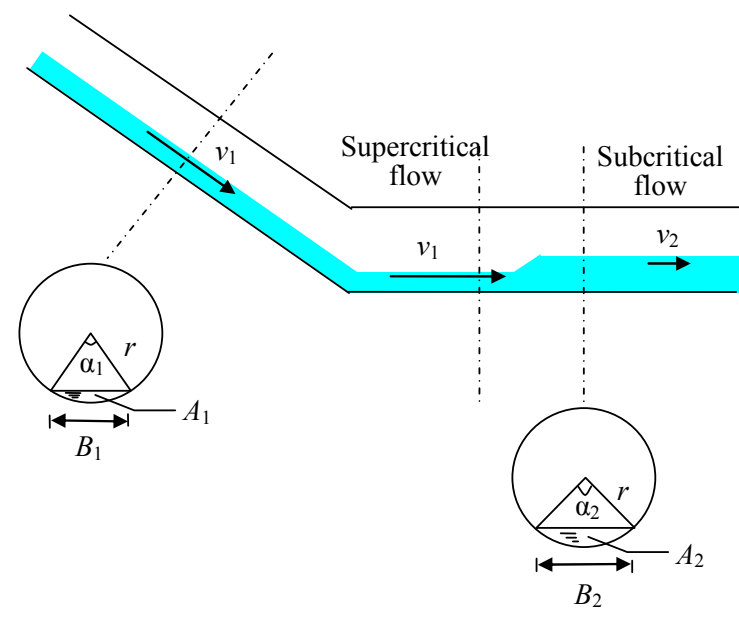

Fig.9 Liquid film flow in pipeline

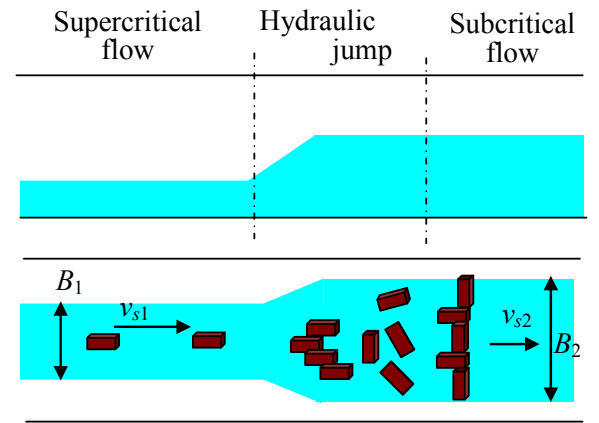

Fig.10 Flow of wood chips in horizontal tube 
図 9 に示されるように, 跳水前の射流部における液膜流の諸特性が，上流部傾斜管 $\left(\theta=30^{\circ}\right)$ 内の液膜流と同じ であると仮定する. 上流部傾斜管における液膜流の等流速度を, 次式に示す Manning の公式 ${ }^{(4)}$ を用いて与える.

$$
v=\frac{1}{n} R^{\frac{2}{3}}\left(I_{e}\right)^{\frac{1}{2}}
$$

ここで, $n$ はマニングの粗度係数であり $n=0.01$ とし， $I_{e}$ はエネルギー勾配であり， $I_{e}=\sin 30^{\circ}$ となる. 径深 $R$ は次式で与えられる.

$$
R=\frac{r}{2} \cdot \frac{\alpha-\sin \alpha}{\alpha}
$$

式(5), 式(8)を式(4)に代入することで，射流部の体積流量が次式で与えられる.

$$
Q_{L}=\frac{r^{2}}{2}\left(\alpha_{1}-\sin \alpha_{1}\right) \times \frac{1}{n}\left(\frac{r}{2} \frac{\alpha_{1}-\sin \alpha_{1}}{\alpha_{1}}\right)^{\frac{2}{3}}\left(I_{e}\right)^{\frac{1}{2}}
$$

式(10)は $Q_{L}$ が与えられた場合, 射流部における液膜流幅の開き角 $\alpha_{1}$ を未知数とする方程式となり, 得られた $a_{1}$ から射流部の $A$ および $h_{m}$ を決定することで， $\left(M_{0}\right)_{1}$ が既知となる. $\left(M_{0}\right)_{1}$ が与えられると，式(1)は常流部にお ける液膜流幅の開き角 $\alpha_{2}$ のみの方程式となる.これを解くことにより跳水位置下流における常流部の液膜流の諸 特性 $A_{2}, B_{2}, h_{m 2}, v_{2}$ が決定できる.

\section{$4 \cdot 2$ アスペクト比を考慮した木質チップの閉塞条件}

液膜流に同伴して輸送される木質チップの平均的な空間間隔 $\Delta x[\mathrm{~m}]$ は木質チップの通過頻度 $n_{S}[1 / \mathrm{s}]$ およ゙木質 チップの平均速度 $v_{S}[\mathrm{~m} / \mathrm{s}]$ により次式で与えられる。

$$
\Delta x=\frac{v_{s}}{n_{s}}
$$

ただし， $n_{S}[1 / \mathrm{s}]$ は木質チップ流量 $Q_{S}\left[\mathrm{~m}^{3} / \mathrm{s}\right]$ を木質チップの体積で除することにより， $v_{S}[\mathrm{~m} / \mathrm{s}]$ は木質チップの密度 が水と同等かそれ以下であるため液膜流平均速度と同じものとして与える.

跳水前後の流動状況の変化および木質チップの配置を図 10 に模式的に示す. 跳水後の常流領域では, 水位の上 昇に伴う液膜流の急激な速度低下に加え, 液膜流幅の増大 $\left(B_{1}<B_{2}\right)$ が観測される. 射流領域における木質チッ プは，長辺方向を液膜流れと平行に一列で流動する．跳水直後では，長辺方向を液膜流れと平行にした状態で液 膜流幅方向に並んだ流動となり，その下流では木質チップが回転し，チップの一部は長辺方向が流れ方向と垂直 な状態に配置される．このとき液膜流幅方向に並ぶ木質チップ数が液膜流幅方向に存在可能なチップ数を超えた とき木質チップが側壁と接触し摩擦抵抗を受けることにより閉塞が発生するものとする.

木質チップの閉塞条件（液膜流幅方向のチップ数=液膜流幅方向に存在可能な最大チップ数）の定式化は以下 の通りである. 液膜流幅方向のチップ数は, 木質チップの長辺長 $s_{l}$ を跳水後の木質チップの平均間隔 $\Delta x_{2}$ で除す ことにより, 液膜流幅方向に存在可能な最大チップ数は常流部の液膜流幅 $B_{2}$ を液膜流幅方向のチップ平均長 $s_{a}$ で除すことで与えられるとし, 次式に示す閉塞条件を得る.

$$
\frac{s_{l}}{\Delta x_{2}}=\frac{B_{2}}{s_{a}}
$$

$\Delta x_{2}$ は常流部の液膜流速度 $v_{2}$ を用いて次式で与えられることから

$$
\Delta x_{2}=\frac{v_{2}}{n_{s}}
$$

木質チップの通過頻度の最大值 $n_{\text {Smax }}$ は次式となる. 


$$
n_{S \max }=\frac{B_{2} \cdot v_{2}}{s_{l} \cdot s_{a}}
$$

チップの体積を $V$ とすると, 常流部の液膜流速度 $v_{2}$ に対する木質チップ最大輸送流量 $Q_{\text {Smax }}$ は次式となる.

$$
Q_{S \max }=n_{S \max } \cdot V=\frac{B_{2} \cdot v_{2}}{s_{l} \cdot s_{a}} \cdot V
$$

常流部の水流幅方向に並ぶチップの平均長 $s_{a}$ は, 短辺と長辺を半分ずつ並べて配置（図 10 の常流部最下流位置 に示す配置）されると仮定し，次式で与える.

$$
s_{a}=\frac{s_{s}+s_{l}}{2}
$$

チップの体積 V は長辺長 $s_{l}$ と短辺長 $s_{s}$ を用いて次式となる.

$$
V=s_{s} \times s_{s} \times s_{l}
$$

式(16) と式(17)を式(15)に代入することで, $Q_{\text {Smax }}$ がチップのアスペクト比 $a$ の関数として次式のように与えられ る.

$$
\begin{aligned}
& Q_{S \max }=\frac{2}{1+a} \cdot s_{s} \cdot B_{2} \cdot v_{2} \\
& a=\frac{s_{l}}{s_{s}} \quad(a \geqq 1)
\end{aligned}
$$

式(18)から, 液膜流量が一定の場合 $\left(B_{2} \cdot v_{2}=\right.$ 一定), アスペクト比 $a$ が大きくなる程 $Q_{S \operatorname{smax}}$ は小さくなることがわ かる. 与えられた $Q_{L}$ に対して, チップアスペクト比 $a=1$ の最大輸送流量 $\left(Q_{\operatorname{Smax}}\right)_{1}$ に対寸るチップアスペクト比 $a$ の最大輸送流量を $\left(Q_{S \operatorname{smax}}\right)_{a}$ の比は, 次式で与えられる.

$$
\frac{\left(Q_{S \max }\right)_{a}}{\left(Q_{S \max }\right)_{1}}=\frac{2}{1+a}
$$

これより，同一 $Q_{L}$ に対する木質チップ最大輸送流量は $a=1$ を基準にした場合， $a=2$ では $2 / 3, a=3$ では $1 / 2$ にな ることがわかる.

式(18)に示した閉塞条件の解析結果と実験結果との比較を図 3 および図 4 に示す. 図中に曲線で示された解析 結果は, チップアスペクト比 $a=1$, 密度 $\rho_{s}=1000 \mathrm{~kg} / \mathrm{m}^{3}$ の場合にのみ観測された $\square$ 印の特別な流動を除き, ○印で 示された実験結果の上限值をほぼ予測できていることがわかる.

図 11 は, 式(20)で示したチップアスペクト比による最大輸送流量の比を実験結果と比較したものである. 図 中の破線が式 (20) を, ○ムがアスペクト比 $a=2$ と $a=3$ の $Q_{L}=3.47 \times 10^{-5} \mathrm{~m}^{3} / \mathrm{s}$ に対する実験結果である. 式(20) の解析が最大輸送流量に及ぼすアスペクト比影響をよくあらわしていることがわかる.

\section{$4 \cdot 3$ 異種アスペクト比チップ混合を考慮した木質チップの閉塞条件}

異種アスペクト比のチップを混合した場合には, 式(12)で用いられた長辺長 $s_{l}$ と常流部の液膜幅方向のチップ の平均長 $s_{a}$ を，等価な值に置き換えることで閉塞条件が与えられるものと考える.

3.3 節で示したアスペクト比 $a=1$ およびアスペクト比 $a=3$ のチップを同体積比で混合した場合を例にして, 検 討を行う.アスペクト比 1 と 3 の木質チップの長辺をそれぞれ $s_{l 1}$ と $s_{l 2}$, 短辺を $s_{s}$ とする. アスペクト比が 1 と 3 のチップの個数比は $3: 1$ となるため, 全チップ個数 $4 n$ の平均值から $s_{l}$ は次式で与えられるものとする.ただし $s_{l 1}=s_{s}$, $s_{l 2}=3 s_{s}$ である. 


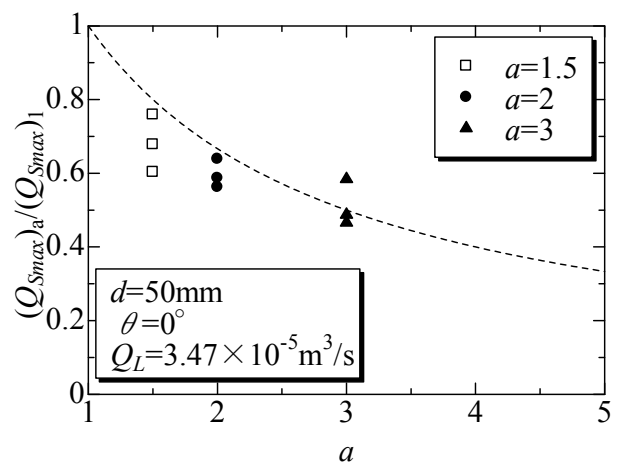

Fig.11 Effect of aspect ratio on transportation limit of wood chips

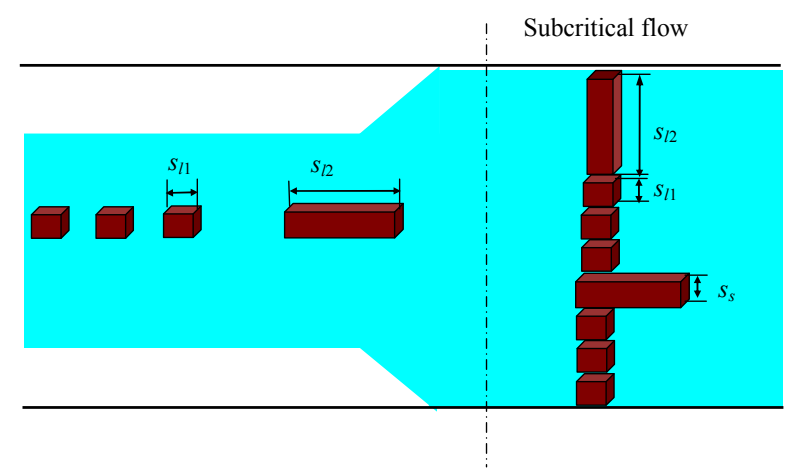

Fig.12 Configuration of wood chips in subcritical flow region

$$
s_{l}=\frac{s_{l 1} \cdot 3 n+s_{l 2} \cdot n}{4 n}=\frac{3}{2} s_{s}
$$

式(21)の結果は, 混合チップの長辺長が短辺長の $3 / 2$ 倍, すなわちアスペクト比 $a=1.5$ に相当することを意味する. 液膜流幅方向の木質チップの平均長 $s_{a}$ は図 12 に示された常流部におけるチップ配置を仮定し, 次式で与えられ るものとする.

$$
s_{a}=\frac{s_{l 1} \cdot 6 n+s_{l 2} \cdot n+s_{s} \cdot n}{8 n}=\frac{5}{4} s_{s}
$$

式(22)は, $a=3$ のチップの半分が長辺方向を液膜流幅方向に, 残りの半分が長辺方向を流れ方向に向けていると仮 定したものであり，式(16)の仮定に準じている．式(21)と式(22)を式(12)に代入して得られる閉塞条件は，式(18) に混合チップの等価なアスペクト比 $a=1.5$ (式(21)）を代入して得られた閉塞条件と同じとなる. 結果的に前節と 同様に式(18)が与えられたチップスペクト比に対する閉塞条件となる.

式(18)の解析結果と実験結果との比較を図 8 に示す. 図中に曲線で示された解析結果は, いずれのアスペクト 比，混合チップにおいても，木質チップ最大輸送流量の実験結果をほぼ予測できていることがわかる.

困 11 の $\square$ 印は混合チップの等価なアスペクト比 1.5 に対する実験結果を表している. 図中の曲線より多少低い值 となっているが， $a=2$ および $a=3$ のデータと合わせて見た場合，本解析モデルで提案する式(18)を用いて木質チ ップ最大輸送流量の予測がおおよそ可能であると言える. 


\section{5. 水力輸送システム運転時のエネルギ一評価}

本研究で提案する水力輸送システムを用いて，林内でチップ化した間伐材を搬出するための所要エネルギーを 検討する. 所要エネルギーとしては, チッパーの動力, 液膜流形成のための水供給ポンプの動力, パイプの敷設 にかかるエネルギーが考えられる．間伐材等の森林バイオマスをチップあるいはペレット燃料として利用するこ とを想定すれば，間伐材を従来の方法で搬出した後においてもチップ化する必要があるため，本研究ではチッパ 一の動力は考慮しない. 以下では, システム運転時のエネルギー評価を目的に, ポンプ動力のみを対象とした所 要エネルギーの見積を行う.

傾斜角が $30^{\circ}$ ，林道からチップ供給地までの斜面に沿う搬出距離と高さがそれぞれ $200 \mathrm{~m}, 100 \mathrm{~m}$ の林内で間伐 材をチップ化し, 水力輸送することを想定する. ただし, 林道からチップ供給地までの水供給管は内径 $50 \mathrm{~mm}$, 長さ $200 \mathrm{~m}$ ，チップ輸送管は内径 $300 \mathrm{~mm}$ ，搬出チップの大きさは $30 \times 30 \times 30 \mathrm{~mm}$ とする. チップ輸送管の一部に は水平な部分も含まれるとする. 与えられた液膜流量 $Q_{L}$ に対して, 水平部での閉塞条件が木質チップの最大輸送 流量を規定するため, 4 章で示した水平管の閉塞解析から $Q_{S \operatorname{Smax}}$ を与える. $Q_{L}$ に対する $Q_{\text {Smax }}$ から, 次式で定義す るポンプの単位エネルギー消費あたりの木質チップ搬出量 $T_{P u m p}\left[\mathrm{~m}^{3} / \mathrm{J}\right]$ 文求まる.

$$
T_{\text {Pump }}=\frac{Q_{S \max }}{\rho_{L} Q_{L} g H}
$$

ただし，分母はポンプ動力[W]であり， $\rho_{L}$ は水密度 $1000\left[\mathrm{~kg} / \mathrm{m}^{3}\right], g$ は重力加速度 $9.8\left[\mathrm{~m} / \mathrm{s}^{2}\right], H$ は全揚程 $[\mathrm{m}]$ を表 す. また， $H$ は，実揚程と水供給管における損失ヘッドの和であり，損失ヘッドは，ダルシー・ワイスバッハの式 を用いて算出した。

図 13 に $Q_{L}$ に対する $T_{P \text { Pump }}$ および $Q_{S \max }$ の変化を示す， $Q_{L}$ 増大により $Q_{S \operatorname{smax}}$ は増加しチップ搬出流量が大きくな る一方において， $T_{P u m p}$ が低下寸ることがわかる，これは，液膜流に同伴してチップ輸送する場合， $Q_{L}$ 増大によ りポンプの単位エネルギー消費あたりの木質チップ量が低下すること, したがって $Q_{L}$ に対して $T_{P u m p}$ と $Q_{\text {Smax }}$ がト レードオフの関係にあることを意味している. これより, 水力輸送システムを用いて木質チップを搬出する場合 には，最適な $Q_{L}$ を選定した上で運転することが必要となる.

参考までに本システム運転時のエネルギー消費量を, 高性能林業機械を用いた木材搬出システムと比較してみ る. 森林総研・原田の報告 (5) によれば, 高性能林業機械を用いて木材 $1 \mathrm{t}$ を伐採搬出するためには, 所要エネル ギーが 180-375MJ 程度と試算されている. 一方, 図 13 に示す本システムの場合, 一日（8 時間稼働）に約 $20 \mathrm{~m}^{3}$ の木質チップを搬出する時, 所要エネルギーは $1.3 \mathrm{MJ} / \mathrm{m}^{3}$ となる. 木質チップ $1 \mathrm{t}$ 当たりの所要エネルギーの換算 に必要な木質チップ密度は, 前報 ${ }^{(2)}$ では含水率 $0 \%$ の杉チップの搬出を仮定して与えたが, 本報ではより現実的 な伐採直後の杉チップ (含水率 50-60\%, 木質チップ密度約 $700 \mathrm{~kg} / \mathrm{m}^{3}$ ) の搬出を想定して単位換算を行った. こ の結果, 木質チップ $1 \mathrm{t}$ 当たりのエネルギー消費量は $2 \mathrm{MJ}$ 程度となり, 搬出規模の差異はあるものの, 高性能林 業機械と比べると，本システムは少量の資源搬出方法として省エネルギ一型の搬出方法といえる.

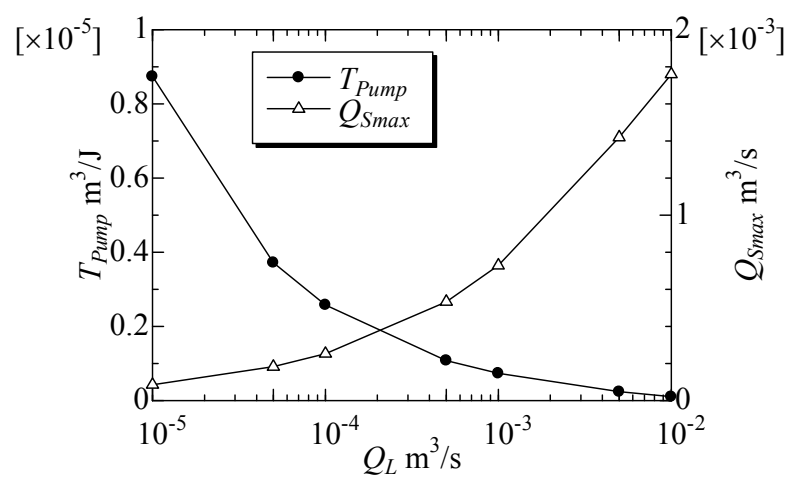

Fig.13 Energy evaluation of hydraulic transportation system 


\section{6. 結 論}

傾斜不整地を模擬した管路による木質チップの水力輸送システムについて検討を行い以下のことが明らかとな った.

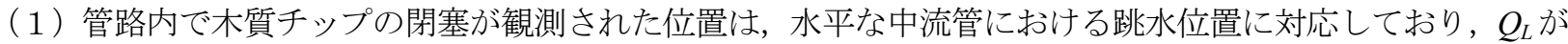
大きくなるほど， $Q_{S \max }$ は大きくなる， $Q_{\operatorname{Smax}}$ に対して，チップ密度の影響は小さいが，管径およびチップアスペ クト比の影響は大きい. 管径が大きく固液混合部直後で閉塞をしない条件であれば，水力輸送される木質チップ 最大輸送流量 $Q_{\text {Smax }}$ に対してチップアスペクト比が大きく影響する.

（2）異種アスペクト比を混合したチップの最大輸送流量 $Q_{S \operatorname{smax}}$ は同一の $Q_{L}$ に対する単独アスペクト比チップ における $Q_{\operatorname{Smax}}$ の中間的な值をとる.

（3）アスペクト比を考慮した木質チップの閉塞条件を提案し，実験結果との比較により解析モデルの妥当性 を示した，異種アスペクト比混合チップでは，等価なアスペクト比を算出することにより，木質チップ最大輸送 流量の予測が可能となる.

（4）水力輸送システムの運転時におけるエネルギー評価から, 液膜流に同伴してチップ輸送する場合, $Q_{L}$ 増 大により $Q_{\operatorname{Smax}}$ が増大すること，一方で $Q_{L}$ 増大によりポンプの単位エネルギー消費あたりの木質チップ搬出量 $T_{P u m p}$ が低下寸ることがわかった。 したがって $Q_{L}$ に対して $T_{P u m p}$ と $Q_{S \operatorname{Smax}}$ がトレードオフの関係にあることを意味 しており, 水力輸送システムを用いて木質チップを搬出する場合には, 最適な $Q_{L}$ を選定した上で運転することが 必要となる.

\section{文献}

（1）農林水産省・バイオマス活用推進基本計画（和文）, http://www.maff.go.jp/j/press/kanbo/bio/101217.html（参照日 2012 年 6 月 25 日).

（2）澤井徹，梶本武志，井田民男，㴊端 学，加治増夫，赤阪素史，“傾斜不整地管路内の液膜流による木質チップ輸 送”，日本機械学会論文集 B 編，Vol.74，No.741（2008），pp.1032-1039.

（3）全国林業改良普及協会，林業技術ハンドブック(2001)，p.1398.

（4）池田駿介，水理学，技法堂出版（1999）, p.249.

（5）原田寿郎，“木質バイオマスのエネルギー利用に関わるエネルギー消費量”，木材工業，Vol.57，No.11（2002）, pp.480-483. 